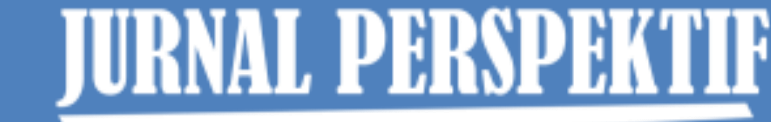

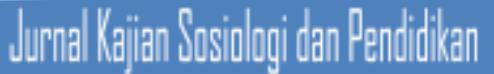

Jurnal Perspektif: Jurnal Kajian Sosiologi dan Pendidikan Vol. 4 No. 4 Tahun 2021

http://perspektif.ppj.unp.ac.id

Email: perspektif@ppj.unp.ac.id

ISSN: 2622-1748 (Online), 2684-902X (Print)

DOI: http://dx.doi.org/10.24036/perspektif.v4i4.540

\title{
Pertukaran Antar Pedagang di Kawasan Objek Wisata Kapalo Banda (Studi Kasus: Nagari Taram Kecamatan Harau Kabupaten Lima Puluh Kota)
}

\author{
Deana Awalia ${ }^{1}$, Nora Susilawati ${ }^{2}$ \\ 1,2Universitas Negeri Padang \\ Email: deanaawalia09@gmail.com., norasusilawati1973@gmail.com
}

\begin{abstract}
Abstrak
Penelitian ini bertujuan untuk menjelaskan bentuk pertukaran antar pedagang serta faktor yang melatar belakangi pedagang melakukan pertukaran di Kawasan Objek Wisata Kapalo Banda Taram. Pedagang memiliki latar belakang yang berbeda, perbedaan tersebut meliputi asal daerah, dan jenis dagangan. Meskipun dilatar belakangi perbedaan antar pedagang, namun interaksi yang terjadi antar pedagang terjalin dengan baik. Interaksi yang baik tersebut menciptakan sebuah interaksi sosial asosiatif berupa pertukaran antar pedagang. Untuk menganalisis penelitian ini, peneliti menggunakan Teori Mekanis dan Organik Emile Durkheim. Metode yang digunakan adalah pendekatan kualitatif dengan tipe studi kasus. Teknik pemilihan informan adalah purposive sampling dengan jumlah informan sebanyak 20 orang. Pengumpulan data dilakukan dengan cara observasi, wawancara dan dokumentasi dengan teknik analisis data interaktif dari Miles dan Huberman. Bedasarkan hasil penelitian yang telah peneliti lakukan, dapat ditarik kesimpulan bahwa ada 4 bentuk terjadinya pertukaran antar pedagang, yaitu: (1) pertukaran Manyalang antar pedagang, (2) Babagi lapak antar pedagang, (3) Batuka Galeh, (4) membantu penjagaan lapak pedagang lain. Dan 5 faktor yang melatarbelakanginya yaitu: (1) Mendapatkan Keuntungan Lebih, (2) Saling Membutuhkan Antar Pedagang, (3) Tolong Menolong Dan Kebersamaan, (5) Adanya Rasa Saling Percaya Antar Pedagang, (5) Munculnya Rasa Empati.
\end{abstract}

Kata Kunci: Kawasan Objek Wisata Kapalo Banda, Pedagang, Pertukaran

\section{Abstract}

This study aims to explain the form of exchange between traders and the factors behind traders cooperating in the Tourism Object Area of Kapalo Banda Taram. After being closed for 4 years due to many irregularities in the area of Kapalo Banda, the Kapalo Banda wa re-opened with a better arrangement and additional potential visits. This make Kapalo Banda crowded with tourists, the hectic visist makes many traders want to sell because they see the potential for profit. Traders have different bagrounds from one another, these different include regional origins, and types of merchandise. Despite the differences between traders, the interactions that occur between traders are well established. This good interaction creates an associative social interaction in the form of exchange between traders.to analyze this research, the researcher used Goerge Casper Homans Theory, namely social exchange. The method used is a qualitative approach with a case study tipe. The informan selection technique was purposive sampling with a total of 20 informants. Data was collected by means of observation, interviews and documentation with interactive data analysis technique form Miles and Huberman.Based on the results of the research that researchers have done, it can be concluded that there are 4 forms of exchange between traders, namely: (1) Manyalang Exchange Between Traders, (2) Babagi Lapak Between Traders, (3) Batuka Galeh, (4) Help Guard The Stalls Of Other Traders. And 5 factors behind it, namely: (!) Profit, (2) Mutual Need Between Traders, (3) Help and Togetherness, (5) Mutual Trust Between Traders, (5) The Emergence of a Sense of Empathy.

Keywords: Exchange, Kapalo Banda Tourism Object Area, Traders. 


\section{Pendahuluan}

Dalam kehidupan sehari-hari seseorang akan melakukan interaksi sosial. Interaksi tersebut terjadi dalam berbagai bidang seperti politik, ekonomi, budaya dan social. Interaksi sosial merupakan kunci dari semua kehidupan, tanpa adanya interaksi sosial tidak mungkin ada kehidupan bersama-sama (Setiawan, 2012). Interaksi yang paling sering dilakukan adalah pada bidang ekonomi salah satu contohnya pada Objek Wisata Kapalo Banda. Kapalo Banda Taram terletak di Kenagarian Taram Kecamatan Harau Kabupeten Lima Puluh Kota, Sumatera Barat. Objek Wisata Kapalo Banda Taram merupakan Objek Wisata alam berupa danau irigasi yang memperlihatkan pemandangan hijau (Indah Prima Wulandari, 2017). Keindahan alam dengan suasana pedesaan yang terdapat di objek wisata tersebut menarik untuk dikunjungi oleh para wisatawan terutama wisatawan yang berasal dari kota. Untuk menikmati suasana di Objek Wisata Kapalo Banda ini pengunjung dikenakan biaya masuk sebesar Rp.5000/orang. Tentu dengan kedatangan pengunjung ini dimanfaatkan oleh masyarakat sekitar objek wisata tersebut untuk membuka peluang kerja sebagai pedagang, baik makanan maupun souvenir.

Lokasi Objek Wisata Kapalo Banda taram tersebut terletak di sekitar hutan dan perbukitan, menjadikan lokasi tersebut banyak terdapat rerumputan tinggi dan semak belukar. Kondisi semak belukar dan rerumputan yang tinggi membuat beberapa tempat sulit untuk dijangkau dan dilihat sehingga tidak terdapat pemantauan yang optimal yang dilakukan oleh pengurus objek wisata tersebut. Hal tersebut membuka peluang orang yang tidak bertanggung jawab untuk melakukan hal-hal yang merugikan seperti perbuatan mesum dan penyalahgunaan barang terlarang. Karena terjadi perbuatan tersebut maka wali nagari taram sepakat untuk menutup obyek wisata tersebut. Hal itu berpengaruh kepada pedagang yang berjualan di sekitar obyek wisata dikarenakan mereka terpaksa harus berhenti berjualan.

Setelah tutup kurang lebih 4 tahun Objek Wisata Kapalo Banda Taram kembali dibuka. Semak belukar diganti dengan berdirinya lapak-lapak pedagang yang tertata dan beraturan. Banyaknya kunjungan wisatawan membuat banyaknya pedagang yang berjualan karena melihat peluang usaha yang bisa mereka dapatkan, Pedagang yang berjualan merupakan pedagang yang menjual makanan dan minuman, serta souvenir berupa gelang, gantungan kunci dan mainan anak-anak. Kedatangan pedagang baru yang berasal dari Nagari Taram dan diluar daerah wisata tersebut menjadikan terciptanya sebuah interaksi sosial antar sesama pedagang.

Bedasarkan hasil wawancara pendahuluan yang dilakukan dengan beberapa pedagang di Objek Wisata Kapalo Banda, Ibu Delfina merupakan seorang pedagang di Kawasan Objek Wisata Kapalo Banda Taram, mengatakan bahwa semenjak dibuka setelah ditutup dengan waktu yang cukup lama banyak terjadi penambahan jumlah pedagang. Lokasi objek wisata yang ada di Nagari Taram menjadikan banyaknya pedagang yang berasal dari desa tersebut yang berjualan, baik yang sudah dari dulu maupun yang baru. Tetapi, pedagang dari luar daerah juga banyak yang datang baik yang daerahnya jauh maupun daerahnya berbatasan dengan Nagari Taram. Walaupun, berasal dari daerah berbeda hubungan yang terjadi antar sesama pedagang terjalin dengan baik. Interaksi yang baik antar pedagang didasarkan adanya proses sosial berupa pertukaran yang dilakukan oleh para pedagang tersebut. Oleh karena itu 
penelitian ini bertujuan untuk mengetahui bagaimana bentuk pertukaran antar pedagang serta faktor yang melatar belakangi pertukaran antar pedagang di Kawasan Objek Wisata Kapalo Banda Taram.

Beberapa hasil penelitian yang relevan dan berhubungan dengan pembahasan pada penelitian ini di antaranya adalah Aji Setyawan.2013. "Interaksi Sosial Antar Pedagang di Dalam Obyek Wisata Ketep Pass Desa Ketep Kecamatan Sawangan Kabupaten Magelang”. Penelitian ini menunjukan bahwa banyaknya wisatawan yang berkunjung mendorong terbentuknya kegiatan ekonomi informal. Berdirinya objek Wisata Ketep membuka lapang pekerjaan bagi warga Desa Ketep dan sekitarnya. Terdapat interaksi sosial antar sesama pedagang, bentuk interaksi sosial yang terjadi antar pedagang di Kawasan Objek Wisata Ketep terlihat dengan adanya kerjasama, persaingan, dan konflik antar sesama pedagang, hasil penelitian ini mengatakan salah satu proses sosial yang terjadi berupa kerjasama yang dipengaruhi oleh kedekatan fisik lapak, kedekatan lingkungan tempat tinggal, kesamaan nasib, kesamaan profesi, dan kesamaan pemikiran. (Setiawan, 2013).

Kedua dari Putri Citra Ningrum 2016 "Hubungan Kerjasama Antar Pengusaha Mebel di Desa Dempelan Kecamatan Madiun Kabupaten Madiun”. Penelitian ini bertujuan untuk menjelaskan hubungan Kerjasama antar pengusaha mebel di Desa Dempelan Kecamatan Madiun Kabupaten Madiun. Hasil dari penelitian ini menunjukan bahwa kontak sosial dan komunikasi menjadi faktor utama terjadinya interaksi sosial pengusaha mebel yang melahirkan proses sosial berupa kerjasama yang terbagi menjadi dua: 1) Pertukaran pengusaha mebel yang memiliki hubungan keluarga Pertukaran dilakukan berupa peminjaman modal dikarenakan rasa kekeluargaan yang masih kuat. 2) pertukaran pengusaha mebel yang tidak memiliki hubungan keluarga. Pertukaran berupa pengadaan alat, pertukaran peminjaman dan kerjasama pengadaan bahan baku(Putri Citra Ningrum_D0311052, n.d.).

Ketiga dari Muh.Nuzuldin.2017 "Interaksi Pedagang Sayur Di Pasar Induk Minasa Maupa Kecamatan Somba Opu Kabupaten Gowa”. Tujuan penelitian ini untuk mengetahui interaksi antar pedagang sayur di Pasar Induk Minasa Maupa Kecamatan Sombu Opa Kabupaten Gowa serta faktor penghambat dan pendukung terjadinya interaksi antar pedagang sayur di Pasar Induk Minasa Maupa Kecamatan Sombu Opa Kabupaten Gowa. Hasil dari penelitian ini adalah interaksi antar pedagang sayur di Pasar Induk Minasa Maupa tersebut terbagi dua yaitu interaksi sosial asosiatif dan disosiatif. Interaksi asosiatifnya berupa pertukaran antar pedagang sayur, pelanggan, tukang angkut, tukang becak, distributor(Nuzuldin, 2017).

Penelian ini berbeda dengan penelitian sebelumnya, dalam penelitian ini fokus penelitian melihat pedagang dalam sektor pariwisata, selanjutnya yang menjadi pembeda penelitian ini adalah lokasi penelitian, dimana peneliti akan melakukan penelitian di Kawasan Objek Wisata Kapalo Banda Taram, Kecamatan Harau, Kabupaten Lima Puluh Kota.

\section{Metode Penelitian}

Pendekatan penelitian ini adalah kualitatif dengan jenis penelitian studi kasus. Melalui penelitian kualitatif peneliti dapat mengenali subjek. Dengan pendekatan kualitatif ini penulis mampu mengungkapkan tentang bentuk pertukaran antar pedagang di Kawasan Objek Wisata Kapalo Banda. Tipe penelitian yang digunakan adalah tipe penelitian studi kasus observasi, observasi yaitu studi yang dilakukan oleh peneliti untuk mengkaji atau menganalisis subjek yang bersifat benda fisik atau suatu proses atau kegiatan yang sedang berlangsung. Untuk itu peneliti menggunakan metode studi kasus observasi untuk mencari jawaban bagaimana 
bentuk kerjasama antar pedagang. Penelitian ini dilakukan di Kawasan Objek Wisata Kapalo Banda Nagari Taram, kecamatan Harau, Kabupaten Lima Puluh Kota. Teknik pengumpulan data yang peneliti gunakan dalam penelitian ini adalah observasi atau pengamatan, wawancara mendalam, dan dokumentasi. Informan dalam penelitian ini sebanyak 20 orang pedagang dan pengelola di Kawasan Objek Wisata Kapalo Banda di Nagari Taram Kecamatan Harau Kabupaten Lima Puluh Kota. Keabsahan data penelitian ini menggunakan triangulasi data dan teknik analisis data menurut miles dan Huberman yaitu reduksi data, penyajian data, dan penarikan kesimpulan.

\section{Hasil dan Pembahasan}

\section{Bentuk Pertukaran Antar Pedagang Di Kawasan Objek Wisata Kapalo Banda Taram}

\section{Pertukaran Manyalang Antar Pedagang}

Manyalang berarti meminjam jika diartikan ke dalam Bahasa Indonesia, pertukaran Manyalang antar pedagang berarti adanya kegiatan meminjam yang dilakukan pedagang di Kawasan Objek Wisata Kapalo Banda. Manyalang yang terjadi antar pedagang ini terbagi menjadi 3 yaitu: Manyalang bahan makanan, Manyalang Pitih (meminjam uang), dan Manyalang barang dagang. Penjelasan antara ketiga pertukaran Manyalang ini dapat dilihat sebagai berikut.

Pertama, Manyalang bahan makanan. Pertukaran ini terjadi antar pedagang makanan karena mereka memiliki jenis dagangan dan bahan dagangan yang sama yaitu makanan. Manyalang bahan makanan adalah meminjam bahan makanan ke pedagang lain yang berjualan makanan, dimana pedagang lain tersebut memiliki bahan yang akan dipinjam. Bahan makanan yang dimaksudkan adalah bahan-bahan seperti mie, minyak goreng, bumbubumbu masakan dan lainnya. Terjadinya bentuk pertukaran berupa Manyalang bahan makanan ini dimaksudkan agar pedagang yang kebetulan kehabisan bahan makanan untuk dijual dapat meminjam bahan makanan tersebut ke pedagang lain, guna untuk menghindari pengunjung tidak jadi membeli dan pedagang masih memiliki peluang mendapatkan keuntungan. Seperti yang diungkapkan ibu Delfina berikut

“...Ibuk memasok barang tidak menentu, terkadang ibuk beli barang banyak tetapi, takut nanti jika tidak habis. Jika ibuk beli barang sedikit takut jika kurang, kadang pengunjung ini datang sedikit terkadang banyak, ketika pengunjung ramai dan kebetulan barang ibuk habis ibuk bisa meminjam ke Ibuk Yanti pedagang sebelah". (Wawancara Tanggal 3 September 2021).

Ibuk Delfina mengungkapkan bahwa, ia menstok bahan makanan tidak menentu disebabkan tidak pastinya jumlah pengunjung yang datang, pada suatu hari bisa saja pengunjung sepi dan ia tidak terlalu banyak menstok bahan makanan, namun pada hari berikutnya tiba-tiba pengunjung ramai yang berdatangan sehingga hal tersebut membuat ia sering kehabisan bahan makanan, untuk itu jika ia kehabisan bahan makanan, Ibuk Delfina meminjam ke Ibuk Yanti karena lapak mereka berdekatan.

Manyalang yang kedua adalah pertukaran Manyalang Pitih yang berarti meminjam uang. Pertukaran Manyalang Pitih ini memiliki persamaan dengan pertukaran Manyalang bahan makanan yaitu sama-sama kegiatan pertukaran yang bersifat meminjamkan ke pedagang lain. Yang menjadi pembeda antara pertukaran Manyalang Pitih dan Manyalang bahan makanan selain perbedaan objeknya yaitu pitih (uang) dan bahan makanan, dalam pertukaran Manyalang bahan makanan, pedagang yang terlibat hanya pedagang makanan, 
Deana Awalia, Nora Susilawati

Pertukaran Antar Pedagang Di Kawasan Objek Wisata Kapalo Banda

(Studi Kasus Nagari Taram Kecamatan Harau Kabupaten Lima Puluh Kota)

sementara dalam pertukaran Manyalang Pitih pedagang yang terlibat adalah seluruh pedagang di Kawasan Objek Wisata Kapalo Banda.

Manyalang Pitih bertujuan untuk memudahkan pedagang apabila menghadapi kendala dalam mengembalikan uang ke pengunjung. Kendala yang dimaksud adalah setelah pengunjung berbelanja dan kemudian membayar ke pedagang dengan nominal uang besar seperti Rp. 100.000 atau Rp.50.000, sementara kondisi pedagang saat itu tidak memiliki uang kembalian dengan nominal kecil seperti Rp. 10.000, Rp. 5000, sampai dengan Rp. 1000 yang cukup untuk mengembalikan uang pengunjung, maka pedagang bisa Manyalang Pitih atau meminjam uang ke pedagang lain untuk mengembalikan uang pengunjungnya, dengan ketentuan pada hari itu juga pedagang tersebut harus mengembalikan uang yang dipinjamnya.

Manyalang yang ketiga adalah Manyalang barang dagang atau meminjam barang dagang. Pertukaran Manyalang barang dagang adalah pertukaran yang dilakukan pedagang yang menjual souvenir dan pedagang mainan anak-anak di Kawasan Objek Wisata Kapalo Banda. Dinamakan Manyalang barang dagang karena pada pertukaran ini pedagang Manyalang atau meminjam berupa barang ke pedagang lainnya. Barang yang di maksud adalah barang-barang souvenir seperti, pajangan, gantungan kunci, gelang dan barang mainan anak-anak seperti, pistol air, pelampung mini, kapal-kapalan, dan lainnya yang dijual pedagang souvenir dan pedagang mainan anak-anak di Kawasan Objek Wisata Kapalo Banda. Manyalang barang dagang hampir mirip dengan pertukaran Manyalang bahan makanan, letak pembeda antara keduanya hanya pada pelaku dan jenis objek yang dipinjam. Jika dalam Manyalang bahan makanan pedagang makanan meminjam ke pedagang lain jika ada bahannya yang habis, maka dalam Manyalang barang dagang, pedagang juga meminjam barang dagang ke pedagang lain yang memiliki dagangan serupa untuk dipinjam dan dijualkan jika barangnya habis. Seperti yang di ungkapkan oleh Bapak Rivan berikut.

“...Saya kan berjualan souvenir disini berdua, jadi pada suatu kesempatan ada pengunjung datang dan bertanya suatu barang yang dia cari, kebetulan barang itu stoknya habis dan di bang Syarisal (pedagang souvenir yang satu lagi) ada stoknya, jadi saya mengambil barang ke bang Syarisal, dan diganti langsung dan dilebihkan dari modal sekitar Rp.5000, karena sebagai laba bang Syarisal memberi saya barang itu". (Wawancara Tanggal 3 September 2021).

Dalam wawancara Bapak Rivan mengatakan bahwa pedagang yang berjualan souvenir di Kawasan Objek Wisata Kapalo Banda hanya ia dan Bapak Syarisal. Pada suatu kesempatan saat ia berjualan, salah satu pengunjung datang dan mencari barang yang dimaksud, barang yang dimaksud pengunjung ternyata habis pada lapak Bapak Rivan dan ada di lapak Bapak Syarisal pedagang souvenir lain. Kemudian Bapak Rivan Manyalang barang dagang dari Bapak Syarisal utuk dijualkan ke pengunjungnya, sebagai gantinya karena telah Manyalang barang dagang ke Bapak Rivan, Bapak Rivan juga mengatakan sering mengganti barang Bapak Syarisal yang di pinjam dengan uang modal dan dilebihkan sekitar Rp.5000 sebagai laba karena sudah meminjamkan Bapak Rivan barang dagang tersebut.

Pada dasarnya ketiga Manyalang ini bersifat meminjamkan, namun yang menjadi pembedanya terletak pada pelaku dan objek yang dipinjamkan. Pertukaran Manyalang bahan makanan pelakunya adalah pedagang makanan, pertukaran Manyalang Pitih (meminjam uang) pelakunya adalah semua pedagang pada Kawasan Objek Wisata Kapalo Banda, sementara Pertukaran Manyalang barang dagang pelaku pertukarannya merupakan pedagang yang menjual souvenir dan pedagang mainan anak-anak di Kawasan Objek Wisata Kapalo Banda. Ketiga pertukaran Manyalang ini memiliki nilai tolong menolong, nilai kebersamaan 
dan nilai saling membutuhkan diantara pedagang di Kawasan Objek Wisata Kapalo Banda. Selain diantara nilai-nilai yang terdapat didalamnya, di dalam pertukaran manyalang, baik itu pertukaran Manyalang bahan makanan, Manyalang Pitih, Manyalang barang dagang.

\section{Babagi Lapak}

Lokasi Kawasan Objek Wisata Kapalo Banda yang dekat dengan perairan dan perbukitan menjadikan tanah di Kawasan Objek Wisata Kapalo Banda ini rentan tergenang air dan becek. Letak Lapak pedagang di Kawasan Objek Wisata Kapalo Banda tersebar di beberapa bagian titik di tepi aliran sungai kecil di sekitar danau irigasi Kapalo Banda. Tanah disekitar aliran sungai kecil di Kawasan Kapalo Banda memiliki struktur yang rentan terhadap debit air yang tinggi, sehingga mudah becek apabila terkena air hujan dengan intensitas yang tinggi.

Hal tersebut menjadi salah satu masalah yang dihadapi oleh beberapa pedagang di Kawasan Objek Wisata Kapalo Banda. Karena masalah ini muncul rasa empati dari para pedagang lain yang lapaknya tidak terkena air hujan untuk membantu sesama pedagang di Kawasan Objek Wisata Kapalo Banda, sehingga terciptanya bentuk pertukaran Babagi Lapak Untuk Pengunjung Pedagang Lain. Babagi artinya adalah berbagi, Babagi lapak untuk pengunjung pedagang lain berarti adanya kegiatan berbagi lapak antara pedagang yang lapaknya tidak bermasalah dengan pedagang yang lapaknya bermasalah, pedagang yang lapaknya memiliki masalah seperti basah atau mengalami kerusakan sehingga tidak memungkinkan untuk menampung pengunjung boleh menumpangkan pengunjungnya pada lapak pedagang lain yang tidak bermasalah, dengan harapan pedagang yang lapaknya memiliki masalah masih bisa memiliki peluang mendapatkan keuntungan.

Ketentuan dalam pertukaran ini adalah pedagang yang menumpangkan pengunjungnya hanya boleh menempati lapak pedagang lain paling banyak 30\% dari bagian lapak itu, atau sekitar 4 sampai 5 orang tergantung lebar masing-masing lapak pedagang. Ketentuan ini dibuat agar pedagang yang ditumpangkan tidak merasa terbebani dan menganggap pedagang yang menumpangkan menghambat pendapatannya karena pengunjungnya tidak dapat duduk.

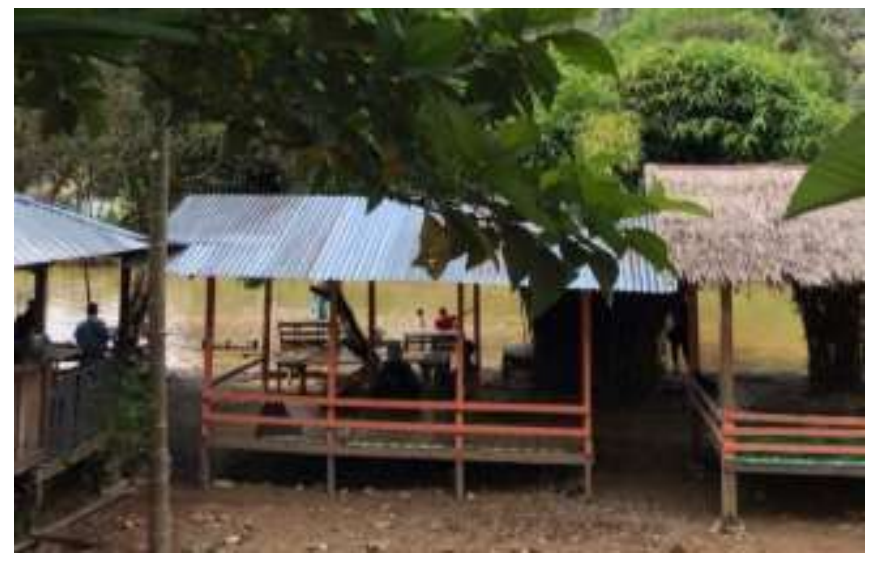

Gambar 1. Lapak Pedagang

Sumber: Dokumentasi Penelitian 4 September 2021

Ukuran lapak di Kawasan Objek Wisata Kapalo Banda beragam, yang paling besar ada yang berukuran $3 \times 3$ meter, umumnya lapak yang ini digunakan untuk pedagang makanan dan minuman dikarenakan pengunjung mereka harus duduk untuk berbelanja atau menikmati 
makanan mereka, sementara lapak untuk pedagang souvenir dan mainan anak-anak hanya berukuran $2 \times 2$ meter atau $2 \times 1$ meter karena pengunjung mereka tidak perlu untuk duduk. Pertukaran Babagi lapak untuk pengunjung pedagang lain terjadi antara pedagang yang memiliki lapak bersebelahan, hal ini dikarenakan ketika pedagang ingin mengantarkan makanan dan pengunjung ingin membayar dengan jarak tidak terlalu jauh. Babagi lapak untuk pengunjung pedagang lain diperuntukkan bagi para pedagang yang memiliki masalah pada lapaknya. Hal ini membantu para pedagang apabila suatu saat memiliki masalah yang mengharuskan mereka memperbaiki lapaknya, namun tidak kehilangan pembeli yang ingin berbelanja. Pertukaran ini dibentuk karena timbulnya rasa empati antar sesama pedagang di Kawasan Objek Wisata Kapalo Banda.

\section{Batuka Galeh}

Batuka Galeh berarti bertukar jualan antar pedagang di Kawasan Objek Wisata Kapalo Banda. Pertukaran Batuka Galeh dibuat dengan tujuan untuk membantu menjualkan barang jualan antar pedagang ke pedagang lain yang memiliki jenis jualan yang sama, seperti pedagang makanan dengan pedagang makanan, pedagang souvenir dengan pedagang souvenir, pedagang mainan anak-anak dengan pedagang mainan anak-anak, ini diadakan untuk mencapai tujuan bersama yang saling menguntungkan kedua belah pihak. Pada Batuka Galeh terdapat proses dimana antar pedagang bertukar jualan mereka untuk dibantu dijualkan oleh pedagang lain. Seperti yang diungkapkan Ibu Delfina dalam kutipan wawancara berikut.

“...Ibuk bertukar dalam bentuk makanan dengan pedagang lain, misalnya dilapak ibuk tidak menjual jagung bakar, nanti jika ada pembeli yang mau jagung bakar, ibuk pesankan ke sebelah ke tempat Bapak FS, jadi kami sama sama dapat rezeki”. (Wawancara Tanggal 10 September 2021).

Dalam wawancara Ibuk Reni yang berjualan makanan dan minuman sebelumnya mengatakan, dalam pertukaran Batuka Galeh ia bepertukaran dengan Bapak FS yang menjual jagung bakar, Ibuk Reni mengatakan jika ada pembeli yang datang ke lapaknya dan menanyakan jagung bakar ia akan menyanggupi permintaan pengunjungnya tersebut meski ia tidak menjual jagung bakar. Permintaan jagung bakar itu Ibuk Reni sampaikan ke Bapak FS, kemudian Bapak FS akan mengantarkan ke lapak Ibuk Reni untuk diberikan kepada pengunjung tersebut. Didalam pertukaran ini keuntungan yang diperoleh Ibuk Reni adalah mendapatkan sebesar Rp. 1000/per satu buah jagung yang ia bantu jualkan. Sementara keuntungan yang diperoleh Bapak FS adalah dagangannya berhasil terjual lewat bantuan lapak Ibuk Reni.

Batuka Galeh melibatkan pedagang-pedagang yang memiliki kategori jualan yang sama namun dengan jenis yang berbeda, hal ini dikarenakan salah satu pedagang tidak berjualan dagangan tersebut maka mereka bertukaran untuk saling menawarkan ke pengunjung barang dagangan masing-masing. Dengan kerja sama ini membuka peluang keuntungan lebih besar kepada pedegang lain yang saling bertukar dagangan, sebab jualan atau barang dagang mereka dapat dibantu dijualkan oleh pedagang lain dan sebaliknya mereka juga membantu menjualkan barang dagangan pedagang lain dilapaknya.

\section{Membantu Penjagaan Lapak Antar Sesama Pedagang.}

Keadaan dan kepentingan mendesak mengakibatkan para pedagang harus meninggalkan lapak mereka yang sebelumnya sudah dibuka atau sedang ada pedagang yang duduk dan makan. Untuk itu dibuatlah sebuah pertukaran yang didasari oleh rasa tolong 
menolong yang dilandasi oleh nilai kepercayaan yang ada antar pedagang di awasan Objek Wisata Kapalo Banda. Pertukaran ini melibatkan pedagang yang memiliki lapak bersebelahan, hal ini dikarenakan mereka tetap bisa memantau lapak pedagang sebelah yang dititipkan maupun lapak mereka dengan jarak yang dekat. Seperti dilihat dalam kutipan wawancara Ibu Delfina berikut.

“...Di lapak kalau tidak ada keluarga yang bisa menolong saat ibuk ada keperluan biasanya ibuk minta tolong ke Melati pedagang sebelah untuk memantau, waktu itu nanti ibuk meminta tolong ke Melati atau Rivan yang bersebalahan sama ibuk untuk mejaga lapak ibuk". (Wawancara Tanggal 4 September 2021).

Dalam kutipan wawancara tersebut, Ibu Delfina mengatakan bahwa ia harus meninggalkan lapaknya jika ada keperluan mendadak. Hal tersebut mengakibatkan lapak Ibuk Delfina terpaksa harus ia tinggalkan. Hal-hal yang terjadi seperti ada orang yang berbelanja tentu sangat memungkinkan. Ketakutan pedagang disaat meninggalkan lapaknya adalah hal tersebut, dimana nanti para pengunjung bisa saja terpaksa pergi dan tidak jadi membeli. Ketakutan kepergian pembeli tersebut menjadikan para pedagang disana meminta bantuan penjagaan lapak kepada pedagang lain. Dimana nanti para pedagang yang memiliki keperluan dan terpaksa harus meninggalkan lapaknya bisa menitipkan lapaknya kepada pedagang disebelahnya. Dalam pertukaran ini pedagang bisa menghindari kerugian pembeli yang pergi karena pedagang tidak ada dilapaknya. Peluang keuntungan bisa di dapatkan melalui pedagang lain yang membantu menjual dagangannya walaupun pedagang tersebut meninggalkan lapak miliknya.

\section{Faktor Yang Melatar Belakangi Pertukaran Antar Pedagang di Kawasan Objek Wisata Kapalo Banda Taram}

\section{Mendapatkan Keuntungan Yang Lebih}

Tujuan utama para pedagang berdagang di Kawasan Objek Wisata Kapalo Banda Taram adalah untuk mencari keuntungan demi memenuhi kebutuhan ekonomi mereka. Pertukaran yang terjalin antar sesama pedagang didasarkan oleh adanya kepentingan ekonomi bagi para pedagang tersebut. Pertukaran di jalankan adalah untuk mencapai tujuan bersama, tujuan bersama para pedagang adalah saling membantu dalam kegiatan ekonomi yang mereka jalankan demi mendapatkan keuntungan lebih. Hubungan pertukaran antar pedagang mengharuskan sesama pedagang saling membantu dalam kegiatan ekonomi yang mereka jalankan. Seperti yang diungkapkan oleh Ibuk Delfina berikut.

“...Kami bertukar untuk sama sama membantu dalam berdagang, tujuan pertukaran untuk mencari keuntungan yang sekiranya bisa kami dapatkan kalau kami bertukar. Misalnya kalau kami tidak bepertukaran dalam pengadaan bahan baku, keuntungan kami yang sepatutnya bisa kami terima tidak bisa gara gara tidak ada pertukaran ini. Tapi, kalau kami bepertukaran kami bisa minjam bahan baku dan kami jadi dapat laba". (Wawancara Tanggal 4 September 2021).

Ibuk Delfina menjelaskan bagaimana pertukaran ini untuk membantu dia memperbesar kemungkinan pendapatan karena adanya bantuan dari pedagang lain. Seperti contoh ketika Ibu Delfina kehabisan bahan makanan, jika tidak ada pertukaran Manyalang bahan makanan maka keuntungannya tidak dapat karena batalnya pesanan. Tetapi, jika Ibuk Delfina bepertukaran Manyalang bahan makanan dan bahannya yang habis dapat dipinjam sehingga 
bisa membuat dagangannya, maka keuntungan tersebut bisa didapatkan dan pembeli jadi membeli dagangannya sehingga keuntungan bisa di dapatkan.

\section{Saling Membutuhkan Antar Pedagang}

Pertukaran antar pedagang di Kawasan Objek Wisata Kapalo Banda juga didasari oleh faktor saling membutuhkan antar pedagang. Hal tersebut dapat dilihat dalam pertukaran Manyalang bahan makanan, Manyalang Pitih, Manyalang barang dagang dan penjagaan lapak pedagang lain. Dalam pertukaran Manyalang, pada dasarnya yang dibutuhkan adalah meminjamkan objek yang dimaksud, baik itu bahan makanan, Pitih, dan barang dagang. Meminjam objek tersebut berarti pedagang itu butuh akan objeknya, seperti pedagang bahan makanan yang meminjam mie, artinya pedagang tersebut butuh akan mie, mie yang ingin dipinjam pedagang merupakan mie yang ada pada pedagang lain.

Antara pedagang yang meminjam, maupun pedagang yang meminjamkan saling melakukan hubungan timbal balik. Pedagang yang meminjamkan bisa jadi pada pertukaran selanjutnya menjadi pedagang yang meminjam, begitupun sebaliknya. walaupun pertukaran ini bertujuan untuk saling membantu para pedagang yang kehabisan bahan untuk tetap bisa berjualan, tetapi didalam pertukaran ini dibutuhkannya peran pedagang lain berupa bantuan pinjaman, sehingga bisa mencapai tujuan tersebut. Maka dari itu faktor yang mendasari terbentuk pertukaran Manyalang ini, baik itu Manyalang bahan makanan, Manyalang Pitih, dan Manyalang barang dagang adalah adanya saling membutuhkan antar pedagang. seperti yang diungkapkan oleh Ibu Delfina berikut.

“...Meminjam itu kan karena kita butuh dengan pedagang lain agar dia mau menolong kita, kalau dia yang meminjam berarti dia juga butuh dengan kita, makanya kita perlu membantu juga kepada pedagang lain”. (Wawancara Tanggal 4 September 2021).

Dalam kutipan wawancara Ibuk Delfina mengatakan, Manyalang itu berarti saling menolong karena pedagang lain itu butuh dengan kita, begitupun dengan kita yang membutuhkan pedagang lain maka dari itu para pedagang melakukan pertukaran Manyalang tersebut, bedasarkan hubungan saling membutuhkan. Hubungan saling membutuhkan antar pedagang tercipta karena proses interaksi yang baik antar pedagang, ketersediaan bahan maupun barang yang dibutuhkan oleh salah seorang pedagang ke pedagang lain yang tidak memiliki barang tersebut menjadi alasan pedagang saling membtuhkan satu sama lain.

\section{Tolong Menolong dan Kebersamaan Antar Pedagang}

Adanya rasa kesamaan profesi yang terjalin antar sesama pedagang menjadikan para pedagang di Kawasan Objek Wisata Kapalo Banda memiliki rasa kebersamaan yang kuat. Ditambah dengan tempat mereka berdagang terletak di kenagarian atau desa yang masih sangat menjunjung tinggi rasa tolong menolong dan kebersamaan menjadikan para pedagang di Kawasan Objek Wisata Kapalo Banda semakin memiliki rasa kebersamaan yang tinggi. Hal inilah yang menyebabkan rasa tolong menolong dan kebersamaan ini sebagai faktor sosial yang melatar belakangi para pedagang di Kawasan Objek Wisata Kapalo Banda melakukan hubungan pertukaran.

Hal tersebut dapat dilihat dari adanya bentuk pertukaran berupa Babagi lapak untuk pengunjung pedagang lain, Manyalang Pitih, dan membantu penjagaan lapak pedagang lain. Hubungan timbal balik yang mereka jalankan menuntut para pedagang harus saling 
melakukan hubungan tolong menolong antar sesama pedagang seperti yang diungkapkan oleh Ibu Emi berikut.

"...Karena sama mencari peruntungan disini kami sudah seperti sama dengan pedagang lain, sering bertemu tiap hari sudah semakin dekat tentunya timbul rasa keluarga, maka karena itu kami bepertukaran menolong pedagang yang lain misalnya kalau mintak dibantu menjaga lapak ya harus dibantu walaupun tidak dikasih laba itu diminta hanya rasa kami saling menolong, kalau saya susah ya dibantu juga nanti sama pedagang lain”. (Wawancara Tanggal 4 September 2021).

Ibu Emi menjelaskan, dalam pertukaran ini walaupun tidak adanya laba atau keuntungan tetapi diminta kepada para pedagang rasa tolong menolong sebagai sesama pedagang di Kawasan Objek Wisata Kapalo Banda. Sebab, kesamaan profesi dan kegiatan ekonomi yang mereka jalankan mengakibatkan mereka bertemu setiap hari dan mengalami interaksi yang sering sehingga semakin mengenal dan akrab. Hal ini menyebabkan timbulnya rasa kebersamaan antar sesama pedagang di Kawasan Objek Wisata Kapalo Banda.

\section{Adanya Rasa Saling Percaya Antar Pedagang}

Adanya rasa saling percaya yang timbul akibat rasa kebersamaan antar pedagang di Kawasan Objek Wisata Kapalo Banda ini menjadikan para pedagang mencipatakan sebuah pertukaran yang dilandasi oleh rasa saling percaya. Pertukaran yang dimaksud adalah Manyalang Pitih dan membantu penjagaan lapak pedagang lain. Dalam pertukaran Manyalang Pitih pedagang yang tidak memiliki uang cukup untuk kembalian akan meminjam ke pedagang terdekatnya untuk mencukupi kekurangan uang kembalian tersebut. Selain pertukaran Manyalang Pitih terdapat juga pertukaran membantu penjagaan lapak pedagang lain, hal ini disebabkan keadaan pedagang yang harus meninggalkan lapaknya dalam keadaan terbuka karena ada suatu keperluan mendesak. Maka dari itu pedagang yang terdekat membantu menjaga lapak pedagang lainnya degan tujuan tidak ada pembeli yang pergi. Dalam pertukaran ini rasa saling percaya di perlukan karena pedagang yang pergi menitipkan sepenuhnya lapak yang ditinggal beserta isinya kepada pedagang yang membantu menjagakan. Seperti yang diungkapkan oleh Bapak FS dalam kutipan wawancara berikut.

“...Saya meminjam uang dan menjaga lapak ke pedagang karena sudah percaya, dan selama ini tidak ada masalah yang timbul karena ini, alhamdulilah pertukaran ini membawa pengaruh baik untuk saya, makanya saya percaya". (Wawancara Tanggal 21 September 2021).

Dalam kutipan wawancara Bapak FS mengatakan, ia meminjamkan uang dan meminta penjagaan lapak ke pedagang lain karena rasa saling percaya selama melaksanakan pertukaran tersebut, Bapak FS tidak menemukan adanya masalah yang timbul, melainkan dampak baik karena terbantu dan saling membantu yang Bapak FS dapatkan, maka dari itu Bapak FS saling percaya dengan pedagang di sekitarnya. Bedasarkan beberapa pernyataan diatas, dapat disimpulkan bahwa adanya rasa saling percaya antar pedagang mengakibatkan munculnya kegiatan pertukaran yang dilakukan. Hal ini paling terlihat jelas pada pertukaran Manyalang Pitih dan membantu penjagaan lapak pedagang lain.

\section{Munculnya Rasa Empati Antar Pedagang}

Empati merupakan rasa mau menolong dan membantu yang timbul kepada orang dalam kejadian yang dialaminya. Munculnya rasa empati ini dapat kita lihat pada Babagi 
lapak kepada pengunjung pedagang lain. Dalam pertukaran itu pedagang yang memiliki masalah pada lapaknya karena hujan lebat sehingga tidak bisa menampung pengunjung boleh menumpangkan pengunjungnya pada lapak pedagang lain. Pertukaran babagi lapak untuk pengunjung pedagang lain ini terjadi karena munculnya empati dari pedagang lain yang lapaknya tidak terkena masalah untuk membantu pedagang yang lapaknya bermasalah agar masih bisa memiliki tempat untuk pengunjungnya. Seperti yang diungkapkan oleh Ibuk Oja dalam kutipan wawancara berikut.

“...Pedagang sebelah saya kalau hujan basah lapaknya, kasihan melihatnya kalau tidak bisa berjualan karena tidak tau dimana mau disuruh duduk pengunjungnya, jadi dipertukaran ini, kami sebagai sesama pedagang, membantu si pedagang yang lapaknya bermasalah, kalau ditempat saya biasanya Ibuk Is yang menumpangkan pengunjungnya”. (Wawancara Tanggal 27 September 2021).

Dalam wawancara Ibuk Oja mengatakan, pertukaran ini dibentuk karena merasa kasihan terhadap pedagang yang lapaknya bermasalah karena hujan lebat, dimana pengunjungnya tidak bisa duduk dan ia tidak bisa berjualan. Oleh sebab itu, di buatlah pertukaran ini demi membantu pedagang lain apabila lapaknya bermasalah karena hujan, ini bentuk rasa membantu antar sesama pedagang di Kawasan Objek Wisata Kapalo Banda.

\section{Pembahasan}

Teori yang dipakai dalam menganalisis penelitian yaitu menggunakan teori solidaritas mekanis dan organik. Teori ini dipopulerkan oleh Durkheim yang tertarik pada cara berubah yang mempersatukan masyarakat dan bagaimana para anggotanya melihat dirinya sebagai bagian dari keseluruhan. Suatu masyarakat yang dicirikan oleh solidaritas mekanis bersatu karena semua orang adalah generalisasi. Ikatan di antara orang-orang itu ialah karena mereka semua terlibat dalam kegiatan-kegiatan yang mirip dan mempunyai tanggung jawab yang mirip. Sebaliknya, suatu masyarakat dicirikan oleh solidaritas organik di persatukan oleh perbedaan-perbedaan diantara orang-orang, oleh fakta bahwa semuanya mempunyai tugastugas dan tanggung jawab yang berbeda(Emile Durkheim di Desa Muara Penimbung et al., n.d.). Masyarakat solidaritas mekanis bersatu kerena mereka semua terlibat dalam kegiatankegiatan yang mirip, seperti pedagang di Kawasan Objek Wisata Kapalo Banda yang saling terikat dikarena kegiatan berdagang mereka di Kawasan Kapalo Banda Taram. Sebaliknya, suatu masyarakat dicirikan organik dipersatukan oleh perbedaan-perbedaan diantara orangorang, seperti di Kawasan Objek Wisata Kapalo Banda para pedagang memiliki perbedaan meliputi asal daerah, umur dan jenis dagangan(Hasan Z, 2015)

Selain menggunakan teori solidaritas mekanis dan organik dari Durkheim, penelitian ini juga menggunakan teori dari Adam Smith yang menjelaskan hubungan antar manusia, para pelaku ekonomi di dalam masyarakat(Atmanti, 2017).

1. Cinta pada diri sendiri dan simpati kepada orang lain. Tindakan ini tergambar dalam kegiatan pertukaran antar pedagang di Kawasan Objek Wisata Kapalo Banda Taram, karena pedagang sebagai aktor ekonomi untuk ingin dihargai oleh orang lain harus mencintai diri sendiri.

2. Keinginan untuk bebas dan keterkaitan pada rasa sopan santun terhadap orang lain. Rasa sopan santun adalah suatu kebutuhan untuk mempertahankan diri dalam kehidupan masyarakat, dalam kegiatan pertukaran antar para pedagang di Kapalo Banda agar memudahkan pertukaran antar pedagang harus ada interaksi yang baik dengan tindakan 
sopan-santun agar hubungan pertukarannya saling menguntungkan satu sama lain oleh kedua belah pihak pedagang yang bertukar.

3. Kebiasaan untuk bekerja, menghasilkan apa yang dibutuhkan, dan kecendrungan untuk mengadakan pertukaran hasil produksi dengan hasil produksi orang lain. Tindakan seperti ini menganggap bahwa ia tidak mampu hidup tanpa orang lain sehingga itu memperoleh kebutuhan dengan melakukan pertukaran sehingga kebutuhan yang tidak mampu dipenuhi dapat terpenuhi oleh orang lain. Contohnya untuk mendapatkan kebutuhan bahan makanan, uang dan barang dagang, para pedagang harus melakukan pertukaran manyalang dengan pedagang lain(Faruq \& Mulyanto, 2017).

Dari teori yang di kemukakan oleh Adam Smith, jelas bahwa dampak dari pertukaran antar pedagang di Kawasan Objek Wisata Kapalo Banda terjadi karena pedagang mampu berinteraksi, saling menghargai sopan santun dan adanya kebiasaan untuk bertukar dengan pedagang lainnya, sehingga dengan demikian mempermudah terjadinya pertukaran antar pedagang di Kawasan Objek Wisata Kapalo Banda Taram(Ninla Elmawati Falabiba et al., 2014).

\section{Kesimpulan}

Bedasarkan hasil penelitian tentang pertukaran antar pedagang di Kawasan Objek Wisata Kapalo Banda, maka dapat ditarik kesimpulan sebagai berikut: bentuk pertukaran pedagang di Kawasan Objek Wisata Kapalo Banda terdiri dari 4 pertukaran yaitu Manyalang antar pedagang, Babagi lapak, Batuka Galeh dan membantu penjagaan lapak pedagang lain. 4 pertukaran ini di dasari oleh 5 faktor yang melatar belakangi yaitu saling membutuhkan, mendapatkan keuntungan yang lebih, saling percaya, saling tolong menolong dan kebersamaan, serta munculnya empati antar pedagang. Faktor yang mendasari pertukaran Manyalang adalah rasa saling membutuhkan dan keinginan mendapatkan keuntungan berlebih, pertukaran Babagi lapak didasari oleh faktor saling menolong, rasa kebersamaan dan munculnya rasa empati antar pedagang, pertukaran Batuka Galeh antar pedagang didasari oleh faktor mendapatkan keuntungan dan saling membutuhkan antar pedagang dan yang terakhir, pertukaran membantu penjagaan lapak pedagang lain, didasari oleh faktor munculnya rasa empati antar pedagang.

\section{Daftar Pustaka}

Atmanti, H. D. (2017). Kajian Teori Pemikiran Ekonomi Mazhab Klasik dan Relevansinya pada Perekonomian Indonesia. Jurnal Ekonomi \& Bisnis, 2(2), 511-524. http://jurnal.untag-sby.ac.id/index.php/JEB17/article/view/1140

Emile Durkheim di Desa Muara Penimbung, S., Indralaya, K., \& Ogan Ilir Diany Rizki Amalia, K. (n.d.). Solidaritas di Antara Pengrajin Songket: Suatu Tinjauan terhadap Teori. $1410-8364$.

Faruq, U. Al, \& Mulyanto, E. (2017). Sejarah Teori-Teori Ekonomi (Issue 1).

Hasan Z. (2015). Teori Solidaritas Emile Durkheim. Uin Sunan Ampel Surabaya, 14, 27-39. http://digilib.uinsby.ac.id/4176/5/Bab 2.pdf

Ningrum, Putri Citra. Kerja Sama Pedagang Mebel Di Desa Dempelan, Kcematan Madiun Kabupaten Madiun. Jurnal_Putri Citra Ningrum_D0311052.(n.d.).

Merliya, M., \& Ikhwan, I. (2019). Pola Interaksi Sosial Pedagang dengan Nelayan di Pasar Ikan Pantai Purus Padang Kecamatan Padang Barat. Jurnal Perspektif: Jurnal Kajian 
Sosiologi Dan Pendidikan, 2(4). http://perspektif.ppj.unp.ac.id

Ninla Elmawati Falabiba, Anggaran, W., Mayssara A. Abo Hassanin Supervised, A., Wiyono, B. ., Ninla Elmawati Falabiba, Zhang, Y. J., Li, Y., \& Chen, X. (2014). Paper Knowledge . Toward a Media History of Documents, 5(2), 40-51.

Nuzuldin, Muhammad. (2017). Interaksi Pedagang Sayur Di Pasar Induk Minasa Maupa Kecamatan Somba Opu Kabupaten Gowa. Occupational Medicine, 53(4), 130.

Setiawan, D. (2012). Journal of Educational Social Studies Interaksi Sosial Antar Etnis Di Pasar Gang Baru Pecinan Semarang Dalam Perspektif Multikultural. In JESS (Vol. 1, Issue 1). http://journal.unnes.ac.id/sju/index.php/jess

Wardani, W. (2016). Membedah Teori Sosiologi : Teori Pertukaran (Exchange Theory) George Caspar Homans. Jurnal Studia Insania, 4(1), 19. https://doi.org/10.18592/jsi.v4i1.1111 